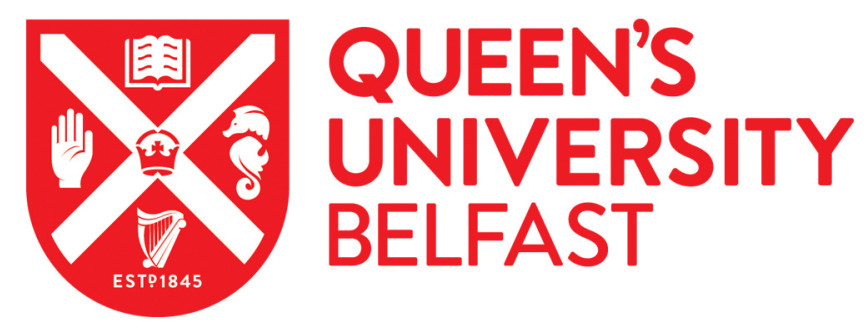

\title{
Total Synthesis of the GRP78-Downregulatory Macrolide (+)- Prunustatin A, the Immunosuppressant (+)-SW-163A, and a JBIR- 04 Diastereoisomer That Confirms JBIR-04 Has Nonidentical Stereochemistry to (+)-Prunustatin A
}

Manaviazar, S., Nockemann, P., \& Hale, K. J. (2016). Total Synthesis of the GRP78-Downregulatory Macrolide (+)-Prunustatin A, the Immunosuppressant (+)-SW-163A, and a JBIR- 04 Diastereoisomer That Confirms JBIR04 Has Nonidentical Stereochemistry to (+)-Prunustatin A. Organic Letters, 18, 2902-2905.

https://doi.org/10.1021/acs.orglett.6b01235

Published in:

Organic Letters

Document Version:

Publisher's PDF, also known as Version of record

Queen's University Belfast - Research Portal:

Link to publication record in Queen's University Belfast Research Portal

\section{Publisher rights}

(C) 2016 American Chemical Society

This is an open access article published under an ACS AuthorChoice License, which permits copying and redistribution of the article or any adaptations for non-commercial purposes.

\section{General rights}

Copyright for the publications made accessible via the Queen's University Belfast Research Portal is retained by the author(s) and / or other copyright owners and it is a condition of accessing these publications that users recognise and abide by the legal requirements associated with these rights.

Take down policy

The Research Portal is Queen's institutional repository that provides access to Queen's research output. Every effort has been made to ensure that content in the Research Portal does not infringe any person's rights, or applicable UK laws. If you discover content in the Research Portal that you believe breaches copyright or violates any law, please contact openaccess@qub.ac.uk. 


\title{
Total Synthesis of the GRP78-Downregulatory Macrolide (+)-Prunustatin A, the Immunosuppressant (+)-SW-163A, and a JBIR- 04 Diastereoisomer That Confirms JBIR-04 Has Nonidentical Stereochemistry to (+)-Prunustatin A
}

\author{
Soraya Manaviazar, Peter Nockemann, and Karl J. Hale*
}

School of Chemistry \& Chemical Engineering and Centre for Cancer Research and Cell Biology (CCRCB), Queen's University Belfast, Stranmillis Road, Belfast BT9 5AG, Northern Ireland, United Kingdom

Supporting Information

ABSTRACT: A unified total synthesis of the GRP78-downregulator (+)-prunustatin $A$ and the immunosuppressant (+)-SW-163A based upon $[1+1+1+1]$-fragment condensation and macrolactonization between $\mathrm{O}(4)$ and $\mathrm{C}(5)$ is herein described. Sharpless asymmetric dihydroxylation was used to set the $\mathrm{C}(2)$ stereocenter present in both targets. In like fashion, coupling of the (+)-prunustatin A macrolide amine with benzoic acid furnished a JBIR-04 diastereoisomer whose NMR spectra did not match those of JBIR-04, thus confirming that it has different stereochemistry than (+)-prunustatin A.

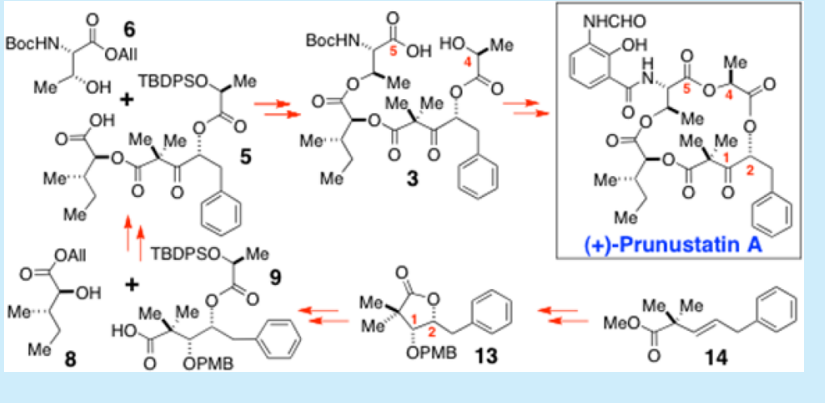

This has prompted a number of groups to devise elegant total syntheses of (+)-prunustatin A to increase the supply, with the teams of Kawanishi ${ }^{3}$ and $\mathrm{Usuki}^{4}$ scoring particularly notable successes in this regard.

Apart from the potential value of GRP78 inhibitors for treating drug-resistant cancers, such molecules could possibly sensitize drug-resistant bacteria to the effects of existing antibiotics (e.g., Gram-negative Neisseria gonorrheae and Neisseria meningitides strains), ${ }^{5}$ and they might also prove useful for counteracting many lethal viral infections. In the latter regard, many viruses rely on GRP78-regulated machinery to create functionally active virions (e.g., the Ebola, Lassa, and Marburg hemorrhagic RNA viruses). ${ }^{5}$ Because of this, we became interested in developing a new synthetic route to (+)-prunustatin $A$ to expedite its future clinical development and that of its powerful reduced immunosuppressant congener, (+)-SW-163A. ${ }^{6}$ In this Letter we report our success in these endeavors.

Following several abortive attempts to synthesize (+)-prunustatin A by strategies involving macrocyclization between $\mathrm{O}(7)$ and $\mathrm{C}(8)$, which each furnished prunustatin $A$ diastereomers, we eventually decided to pursue a new synthetic plan wherein the $\mathrm{C}(1)$ keto group would be installed before ring closure between (O) 4 and C(5). In our newly proposed strategem (Scheme 1), a late-stage macrolactonization would now be effected on seco-acid 3. ${ }^{3}$ The resulting macrolide would then be converted into amine-lactone 2 , which would be coupled to acid $\mathbf{1}$. The resulting product would then be O-debenzylated. Compound 3 would itself be acquired from 4 by $\mathrm{O}$-deallylation and $\mathrm{O}$ -

Received: April 29, 2016

Published: May 27, 2016 
Scheme 1. Our Retrosynthetic Planning for Prunustatin A

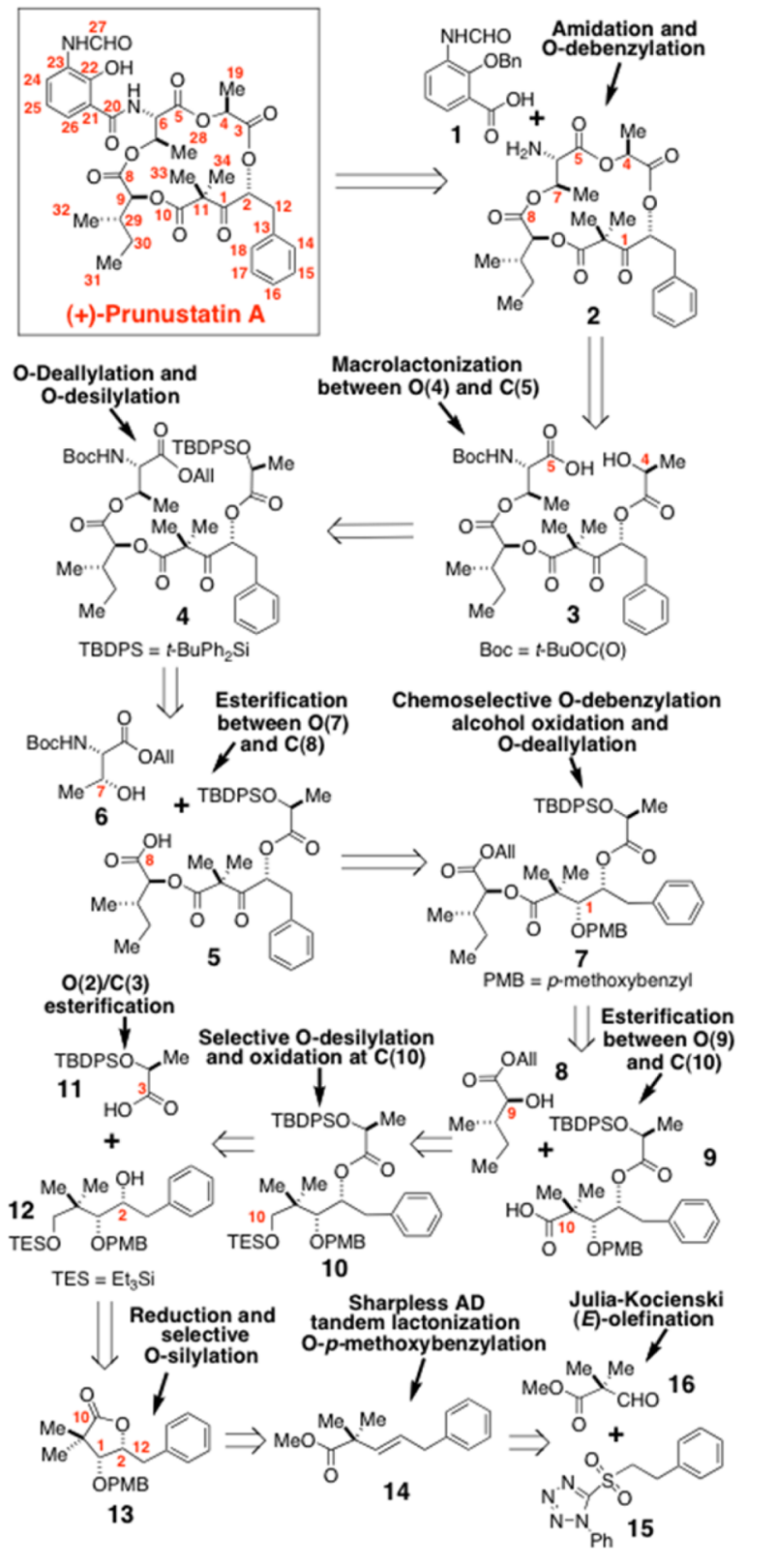

desilylation, with tetraester 4 being assembled from the sterically hindered acid 9 by two successive esterifications, the first involving 8 and 9 and the second involving 5 and 6 . Keto acid 5 would be derived from triester 7 by O-debenzylation at $\mathrm{C}(1)$, oxidation of the alcohol to the ketone, and O-deallylation. Acid 9 was envisioned to emanate from alcohol 12 by esterification with protected L-lactic acid derivative $\mathbf{1 1}$ allied with selective $\mathrm{O}$ desilylation and oxidation of the primary alcohol to the acid. The main issue associated with constructing alcohol 12 would be correct positioning of the various protecting groups to enable the alcohol at $\mathrm{C}(2)$ to be selectively presented to $\mathbf{1 1}$. For this, we hoped to take advantage of a Sharpless asymmetric dihydroxylation $(\mathrm{AD})$ reaction $^{7}$ on $(E)$-alkene 14 accompanied by in situ lactonization to give the corresponding $\beta$-hydroxybutyrolactone with high ee. If successful, such an approach would nicely allow protection of the secondary hydroxyl at $\mathrm{C}(1)$ as an $O-p$ methoxybenzyl (OPMB) ether, as in compound 13, to allow the remaining features to be elaborated by reduction and selective $\mathrm{O}$ - silylation. Of course, a good option for constructing the $(E)$ olefin in 14 would be a Julia-Kocienski olefination ${ }^{8}$ between tetrazolylsulfone 15 and known $\beta$-aldehydo ester $16 .{ }^{9}$

Our new (+)-prunustatin A campaign began with a repetition of the synthesis of $\beta$-aldehydo ester $16,{ }^{9}$ which was typically prepared in $67 \%$ yield from 17 by pyridinium chlorochromate (PCC) oxidation in $\mathrm{CH}_{2} \mathrm{Cl}_{2}$ (Scheme 2). Aldehyde 16 was then

Scheme 2. Our Synthesis of Acid 9

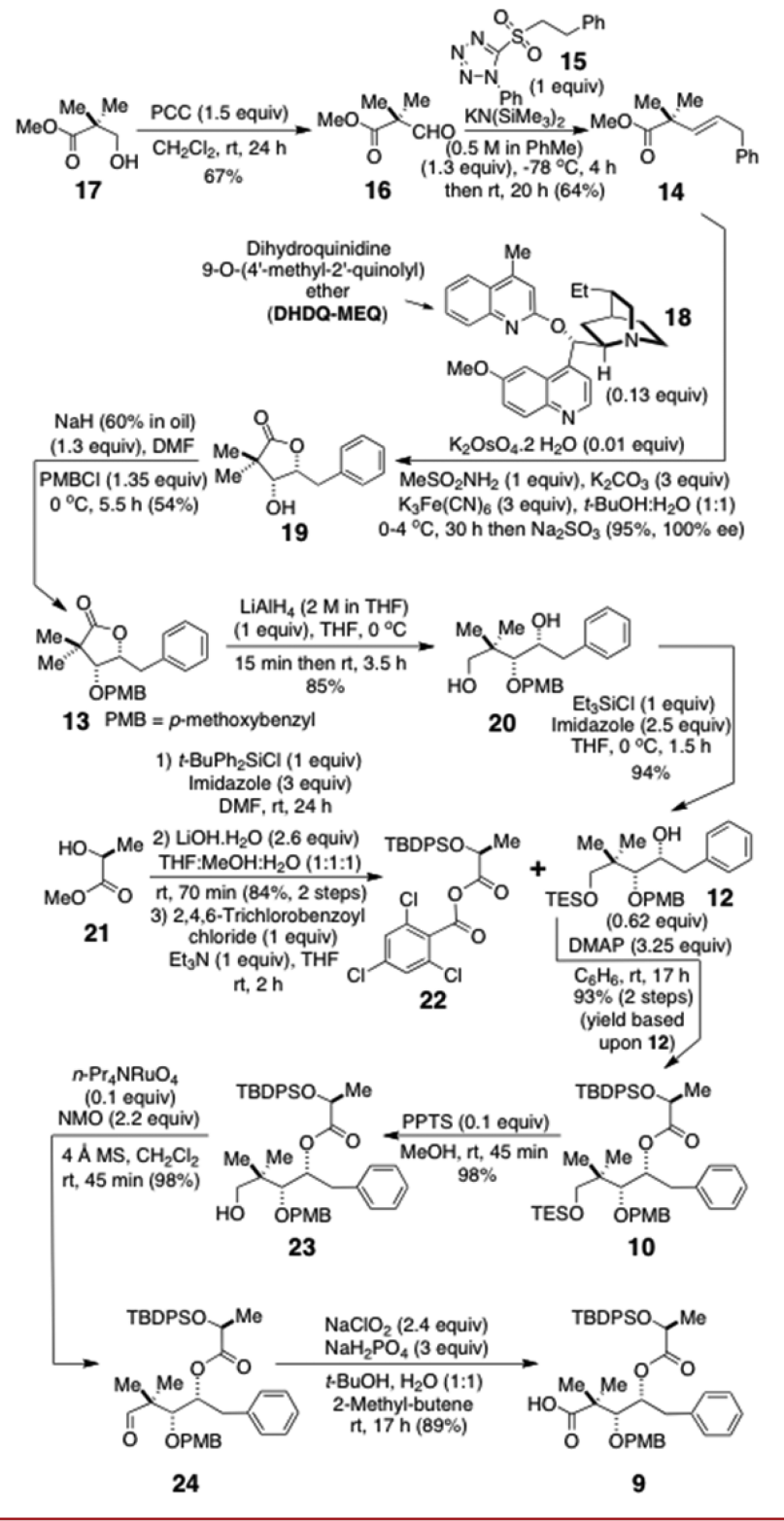

condensed with the anion derived from 15 to give $(E)$-alkene 14 in $64 \%$ yield with total stereocontrol. While initially we accessed 19 in near optically pure condition via Sharpless $\mathrm{AD}$ with $\mathrm{AD}$ mix $-\beta{ }^{7 a}$ we found this process to be inconveniently slow, needing 7 days to reach completion. We therefore evaluated less hindered Sharpless ligands for this purpose. A considerable improvement in the reaction rate was found when the $\mathrm{AD}$ was conducted with catalytic potassium osmate $(1 \mathrm{~mol} \%)$ and the DHQD-MEQ ligand ${ }^{7 \mathrm{~b}}(13 \mathrm{~mol} \%)$, which afforded the lactonized product 19 in $95 \%$ yield with $100 \%$ ee after only 30 $\mathrm{h}$ of stirring at $0{ }^{\circ} \mathrm{C}$, which represented a considerable 
operational improvement and was also much cheaper to carry out.

The alcohol in 19 was then protected as an OPMB ether with $\mathrm{NaH}$ and $\mathrm{PMBCl}$ in $\mathrm{DMF}$, and the product, lactone 13, was reduced with $\mathrm{LiAlH}_{4}$ to obtain diol 20 in $85 \%$ yield. The less hindered primary hydroxyl of 20 was next regioselectively protected as an $\mathrm{O}$-triethylsilyl (OTES) ether to allow the allimportant ester bond to be grafted onto $\mathrm{O}(2)$. For this, $(S)$-lactic acid derivative 21 was first converted into the Yamaguchi ${ }^{10} 2,4,6$ trichlorobenzoic acid mixed anhydride $\mathbf{2 2}$, and this was reacted with 12 in $\mathrm{C}_{6} \mathrm{H}_{6}$ at $\mathrm{rt}$ for $17 \mathrm{~h}$ in the presence of 4(dimethylamino)pyridine (DMAP) (3.25 equiv). This proved to be the optimal method for esterifying this system, furnishing 10 in 93\% yield. Having reliably fulfilled its alcohol-differentiating role, the primary OTES ether was selectively cleaved from 10 by catalytic pyridinium $p$-toluenesulfonate (PPTS) (0.1 equiv) in $\mathrm{MeOH}$ over $45 \mathrm{~min}$ at rt. A two-stage oxidation thereafter converted alcohol 23 into carboxylic acid 9. In this sequence, a Ley-Griffith catalytic $n-\mathrm{Pr}_{4} \mathrm{NRuO}_{4} / \mathrm{N}$-methylmorpholine $\mathrm{N}$-oxide (NMO) oxidation ${ }^{11}$ first furnished aldehyde 24 in near quantitative yield, and a Pinnick oxidation subsequently provided 9 in $89 \%$ yield. $^{12}$

We next focused our attention on converting L-isoleucine (25) into L-isoleucic acid (26) and the latter into $O$-allyl ester 8 (Scheme 3). ${ }^{13}$ To access the former, we followed the diazotization procedure of Plenkiewicz and Poterala, ${ }^{13 a}$ which worked very well in our hands, and generated the $\mathrm{HNO}_{2}$ in situ from $1 \mathrm{M}$ aqueous $\mathrm{H}_{2} \mathrm{SO}_{4}$ and $\mathrm{NaNO}_{2}$. It delivered the crystalline acid 26 in $76 \%$ yield on a large scale from 25 (53 g). Chemoselective O-allylation ${ }^{13 \mathrm{~b}}$ was next achieved with $\mathrm{K}_{2} \mathrm{CO}_{3}$ /allyl bromide/ $\mathrm{Bu}_{4} \mathrm{NI}$ in DMF at $\mathrm{rt}$; the product ester 8 was isolated in $82 \%$ yield. It was then coupled to acid 9 using excess $\mathrm{N}$-(3-(dimethylamino)propyl)- $\mathrm{N}$-ethyl carbodiimide hydrochloride (EDCI) and DMAP as the acid activators; triester 7 was formed in $72 \%$ yield after $18 \mathrm{~h}$ of stirring at $\mathrm{rt}$ in $\mathrm{CH}_{2} \mathrm{Cl}_{2}$.

DDQ was now used to chemoselectively remove the PMB group from $\mathrm{O}(1)$ without disturbing the potentially sensitive $O$ allyl ester. The resulting alcohol 27 was oxidized to the ketone with $n$ - $\mathrm{Pr}_{4} \mathrm{NRuO}_{4} / \mathrm{NMO}$ in $\mathrm{MeCN}$, and the $O$-allyl ester was detached with $\mathrm{PhSiH}_{3}$ and $\mathrm{Pd}(0)$. The acid 5 so produced was then coupled to partially protected L-threonine derivative 6 using 2-methyl-6-nitrobenzoic anhydride (MNBA) ${ }^{14}$ and DMAP in $\mathrm{CH}_{2} \mathrm{Cl}_{2}$, affording the desired product 4 in $74 \%$ yield. Subsequently, 4 was O-deallylated with $\mathrm{PhSiH}_{3}$ and catalytic $\mathrm{Pd}\left(\mathrm{PPh}_{3}\right)_{4}$ in $\mathrm{CH}_{2} \mathrm{Cl}_{2}$, ${ }^{15}$ and the product acid was O-desilylated with HF-pyridine complex in a mixture of pyridine/THF. Both deprotections proceeded cleanly to provide the required secoacid 3 in $82 \%$ yield over the two steps. The latter was then macrolactonized on a $0.3 \mathrm{~g}$ scale under high-dilution conditions by addition of a solution of 3 in $\mathrm{CH}_{2} \mathrm{Cl}_{2} / \mathrm{THF}(1: 1)$ over $9 \mathrm{~h}$ to a solution of DMAP ( 2 equiv) and $\mathrm{MNBA}^{14}$ (1.3 equiv) in dry THF at rt, attaining a final reaction concentration of ca. 0.00048 $\mathrm{M}$ with respect to 3 . The reactants were then allowed to stir at rt for $39 \mathrm{~h}$ to bring about the desired ring closure. Macrolide 29 was isolated pure in $42 \%$ yield after $\mathrm{SiO}_{2}$ flash chromatography. The structure of $\mathbf{2 9}$ was unambiguously confirmed by single-crystal Xray analysis (see the Supporting Information). Importantly, the $400 \mathrm{MHz}{ }^{1} \mathrm{H}$ NMR spectrum of 29 in $\mathrm{CDCl}_{3}$ matched that of Kawanishi.

Although we did attempt to repeat the $50{ }^{\circ} \mathrm{C}$ macrolactonization protocol of Yamakoshi and Kawanishi ${ }^{3,16}$ on $\mathbf{3}$ at the reaction concentration of $0.0012 \mathrm{M}$ that they reported, we found it extremely difficult to control the rate of the addition of
Scheme 3. Completion of Our Total Synthesis of (+)-Prunustatin A and the Immunosuppressant SW-163A

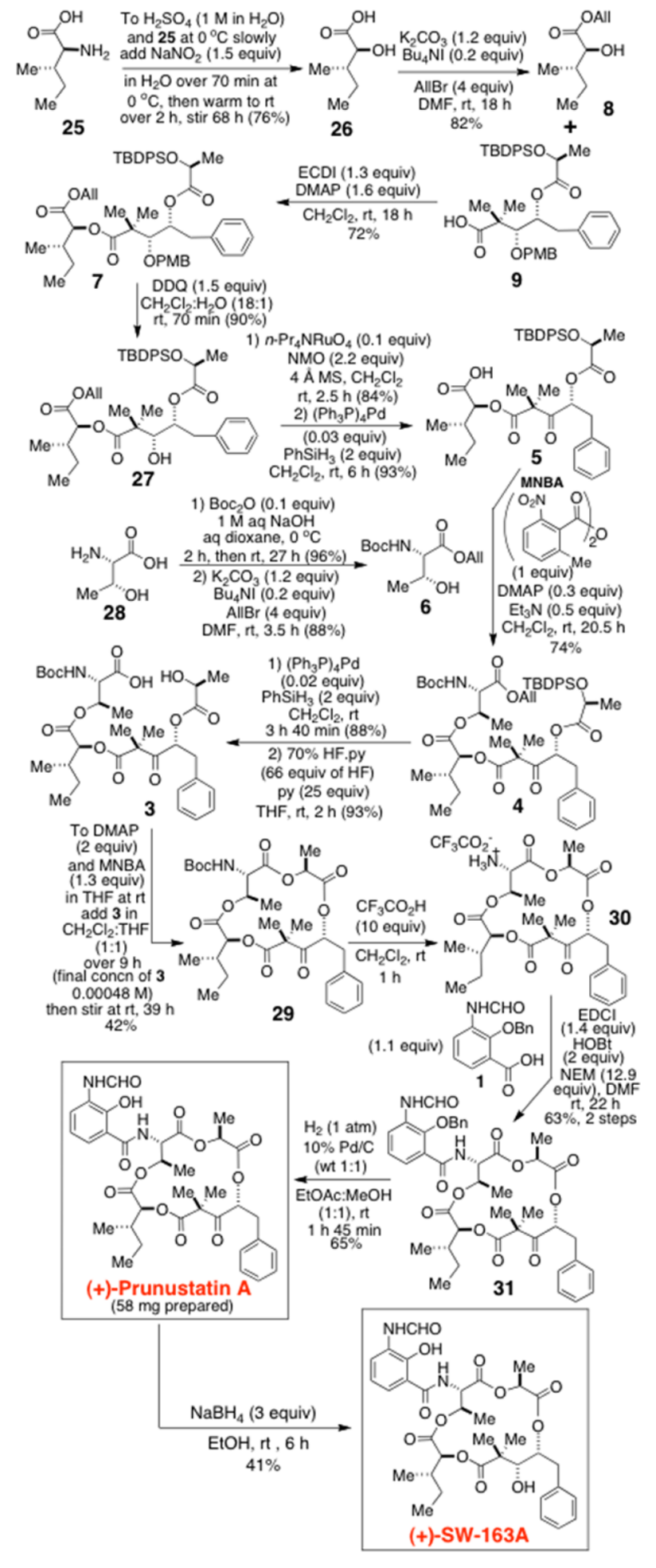

the seco-acid solution to the MNBA/DMAP solution, when either a syringe pump or slow cannulation was used to deliver the $\mathrm{THF} / \mathrm{CH}_{2} \mathrm{Cl}_{2}$ solution of 3 . Not only did the hot vapor from the reaction mixture consistently oppose a carefully controlled slow addition of the solution of 3 into the reaction flask, but also, the heating process caused much more variable reaction outcomes, with the attendant formation of more complex mixtures. Our very best yield of 29 from adhering to the $50{ }^{\circ} \mathrm{C}$ cyclization 
protocol in ref 3 was $49 \%$, but this was not the norm. Because of the significant technical difficulties and reaction variations that attend this method, ${ }^{3}$ we recommend that other workers use the much more consistent ultrahigh-dilution rt cyclization procedure that we have described in the Supporting Information. However, even under our rt conditions, intermolecular dimerization of 3 still continues to be significant, but generally less so than under the 50 ${ }^{\circ} \mathrm{C}$ reaction conditions. ${ }^{3,16}$

In order to complete our synthesis of $(+)$-prunustatin $\mathrm{A}$, the Boc group of 29 was detached with neat $\mathrm{CF}_{3} \mathrm{CO}_{2} \mathrm{H}$ in $\mathrm{CH}_{2} \mathrm{Cl}_{2}$, and the crude TFA salt 30 was coupled with $1^{3,4,18}$ using EDCI, $\mathrm{N}$-ethylmorpholine (NEM), and 1-hydroxybenzotriazole (HOBt). The desired product 31 was isolated in 63\% yield after $\mathrm{SiO}_{2}$ flash chromatography; it was identical to the same compound prepared by Usuki. ${ }^{4}$ Compound 31 was then deprotected by catalytic hydrogenation with $10 \% \mathrm{Pd} / \mathrm{C}$ in EtOAc/MeOH (1:1) at $1 \mathrm{~atm}$; synthetic (+)-prunustatin A was isolated in $65 \%$ yield after $\mathrm{SiO}_{2}$ chromatography ( $0.74 \%$ overall). Its spectroscopic values closely matched those reported by Shinya, ${ }^{1,2}$ Kawanishi, ${ }^{3}$ and Usuki, ${ }^{4}$ thus confirming that the natural product had indeed been synthesized. $\mathrm{NaBH}_{4}$ reduction of (+)-prunustatin $\mathrm{A}$ in $\mathrm{EtOH}$ also furnished the immunosuppressant (+)-SW-163A, ${ }^{6}$ in accord with Shin-ya's 2007 limited report. ${ }^{2}$

Given that we had unambiguously proven the stereochemistry of 29, we next deprotected its Boc group and coupled 30 to $\mathrm{PhCO}_{2} \mathrm{H}$ in order to secure what we hoped was going to be the structurally related natural product JBIR- $04^{17}$ (Scheme 4),

Scheme 4. Our Attempted Synthesis of JBIR-04
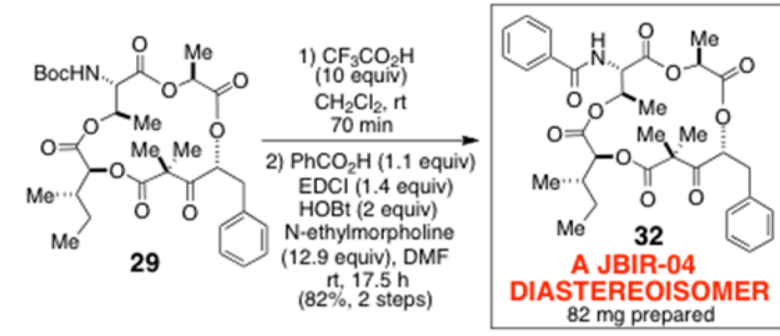

whose absolute stereostructure has not been assigned to date. Unfortunately, our spectroscopic comparisons of $\mathbf{3 2}$ with JBIR04 soon confirmed that JBIR-04 has different absolute stereochemistry than $(+)$-prunustatin $\mathrm{A}$, which perhaps explains why its GRP78-downregulatory effects are 200 times lower.

In conclusion, we have devised unified, highly stereoselective total syntheses of (+)-prunustatin A, SW-163A, and JBIR-04 diastereoisomer 32. ${ }^{18}$ The latter synthesis also revealed that the absolute stereochemistry of JBIR-04 differs from that found in (+)-prunustatin A. We expect that our new synthetic pathway to these molecules will prove useful for fashioning analogues, including biotinylated ones, which would have potential value for new drug target retrieval by affinity chromatography.

\section{ASSOCIATED CONTENT}

\section{S Supporting Information}

The Supporting Information is available free of charge on the ACS Publications website at DOI: 10.1021/acs.orglett.6b01235.

Full experimental procedures for all steps, copies of the IR, HMRS, and ${ }^{1} \mathrm{H} /{ }^{13} \mathrm{C}$ NMR spectra of every intermediate, and X-ray plots and crystallographic data for 19, 13, and 29 (including CCDC accession numbers) (PDF)
SQUEEZE-processed crystallographic data for $\mathbf{2 9}$ (CIF) Original crystallographic data for 29 (CIF)

Crystallographic data for 13 (CIF)

Crystallographic data for 19 (CIF)

\section{AUTHOR INFORMATION}

\section{Corresponding Author}

*k.j.hale@qub.ac.uk

Notes

The authors declare no competing financial interest.

\section{ACKNOWLEDGMENTS}

We thank QUB and the ACS for helping to fund this work. We are also extremely grateful to Dr. Eiji Kawanishi of Mitsubishi Tanabe Pharma for very kindly supplying us with PDF copies of his spectra for (+)-prunustatin A, SW-163A, and macrolide 29.

\section{REFERENCES}

(1) Umeda, Y.; Chijiwa, S.; Furihata, K.; Furihata, K.; Sakuda, S.; Nagasawa, H.; Watanabe, H.; Shin-ya, K. J. Antibiot. 2005, 58, 206.

(2) Umeda, Y.; Furihata, K.; Sakuda, S.; Nagasawa, H.; Ishigami, K.; Watanabe, H.; Izumikawa, M.; Takagi, M.; Doi, T.; Nakao, Y.; Shin-ya, K. Org. Lett. 2007, 9, 4239.

(3) Yamakoshi, S.; Kawanishi, E. Tetrahedron Lett. 2014, 55, 1175.

(4) Usuki, Y.; Ogawa, H.; Yoshida, K.; Inaoka, T.; Iio, H. Asian J. Org. Chem. 2015, 4, 737.

(5) Booth, L.; Roberts, J. L.; Cash, D. R.; Tavallai, S.; Jean, S.; Fidanza, A.; Cruz-Luna, T.; Siembiba, P.; Cycon, K. A.; Cornelissen, C. N.; Dent, P. J. Cell. Physiol. 2015, 230, 1661.

(6) Takahashi, K.; Tsuda, E.; Kurosawa, K. J. Antibiot. 2001, 54, 867.

(7) (a) Sharpless, K. B.; Amberg, W.; Bennani, Y.; Crispino, G. A.; Hartung, J.; Jeong, K. S.; Kwong, H. L.; Morikawa, K.; Wang, Z. M. J. Org. Chem. 1992, 57, 2768. (b) Sharpless, K. B.; Amberg, W.; Beller, M.; Chen, H.; Hartung, J.; Kawanami, Y.; Lubben, D.; Manoury, E.; Ogino, Y.; Shibata, T.; Ukita, T. J. Org. Chem. 1991, 56, 4585.

(8) Blakemore, P. R.; Cole, W. J.; Kocienski, P. J.; Morley, A. Synlett 1998, 1998, 26.

(9) Hale, K. J.; Grabski, M.; Manaviazar, S.; Maczka, M. Org. Lett. 2014, 16, 1164.

(10) Inanaga, J.; Hirata, K.; Saeki, H.; Katsuki, T.; Yamaguchi, M. Bull. Chem. Soc. Jpn. 1979, 52, 1989.

(11) $n-\mathrm{Pr}_{4} \mathrm{NRuO}_{4} / \mathrm{NMO}$ review: Ley, S. V.; Norman, J.; Griffith, W. P.; Marsden, S. P. Synthesis 1994, 1994, 639.

(12) Bal, B. S.; Childers, W. E., Jr.; Pinnick, H. W. Tetrahedron 1981, 37, 2091.

(13) (a) Diazotization method: Poterala, M.; Plenkiewicz, J. Tetrahedron: Asymmetry 2011, 22, 294. (b) Elgersma, R. C.; Meijneke, T.; Posthuma, G.; Rijkers, D. T. S.; Liskamp, R. M. J. Chem. - Eur. J. 2006, 12, 3714.

(14) Shiina, I.; Kubota, M.; Ibuka, R. Tetrahedron Lett. 2002, 43, 7535.

(15) Dessolin, M.; Guillerez, M.-G.; Thieriet, N.; Guibe, F.; Loffet, A. Tetrahedron Lett. 1995, 36, 5741.

(16) Because ref 3 reports no experimental procedures at all, we reproduced as best we could the $50{ }^{\circ} \mathrm{C}$ macrocyclization in THF/ $\mathrm{CH}_{2} \mathrm{Cl}_{2}$ outlined in that paper.

(17) Izumikawa, M.; Ueda, J.; Chijiwa, S.; Takagi, M.; Shin-ya, K. J. Antibiot. 2007, 60, 640.

(18) Recent syntheses of respirantin and kitastatin: (a) Pettit, G. R.; Smith, T. H.; Feng, S.; Knight, J. C.; Tan, R.; Pettit, R. K.; Hinrichs, P. A. J. Nat. Prod. 2007, 70, 1073. (b) Beveridge, R. E.; Batey, R. A. Org. Lett. 2014, 16, 2322. 